\title{
IMPACT OF HYDROTECHNICAL STRUCTURES ON HYDROLOGICAL REGIME OF THE GWDA AND DRAWA RIVERS
}

\author{
Katarzyna Kubiak-WójcickA ${ }^{1}$, Marika Kornaś ${ }^{1,2}$ \\ ${ }^{1}$ Nicolaus Copernicus University, Torun, Poland \\ ${ }^{2}$ Institute of Meteorology and Water Management - National Research Institute, Wrocław, Poland
}

Manuscript received: June 15, 2013

Revised version: January 28, 2015

\begin{abstract}
KubiaK-Wójcicka K., Kornaś M., 2015. Impact of hydrotechnical structures on hydrological regime of the Gwda and Drawa rivers. Quaestiones Geographicae 34(1), Bogucki Wydawnictwo Naukowe, Poznań, pp. 99-110, 3 tables, 7 figs. DOI 10.1515/quageo-2015-0009, ISSN 0137-477X.

ABSTRACT: The work attempts to determine the impact of hydrotechnical structures on regimes of rivers. The aim of the article is to compare hydrological regimes of the rivers Gwda and Drawa due to the differences of hydrotechnical works located on both rivers. The Gwda River is heavily managed by hydrotechnical infrastructure. Presently, there are twelve hydropower plants located along the entire length of the river. The Drawa River, on the other hand, has little hydrotechnical infrastructure. Only two hydropower plants are located on the Drawa River. The study of the hydrological regime was carried out on the basis of the analysis of changes of water stages and ice phenomena. River profiles selected for the analysis were located downstream of hydrotechnical works, i.e. hydropower plants. The conclusions were based on the comparative analysis. The impacts were identified as the differences in processes described by the analyzed parameters.
\end{abstract}

KEY wORDS: hydrotechnical works, hydrological regime, the Gwda River, the Drawa River

Address of the corresponding author: Katarzyna Kubiak-Wójcicka, Nicolaus Copernicus University, Torun, Poland; e-mail:kubiak@umk.pl

\section{Introduction}

The hydrological regime, in general, often specified as the river regime describes the state and reactions of river's catchment in relations to the climate system and physiogeographic features of the catchment (Gutry-Korycka 2001). It denotes a certain type of variability of a certain phenomenon in the nature. That variability pertains most frequently to any action related to a river, e.g. ice, water stages or discharge (Dynowska 1972). It is also defined as a kind and time distribution of river discharge during a regular annual course. More specific, it is identified with the runoff regime. There are many different ways of deter- mining features of runoff regime. Most often, the regime includes variability of water stages and river discharges in the period of multiyear, a year or a season (Dynowska 1972, Rotnicka 1988, Piętka 2009). Specific runoff is a measure of river discharge. Two different approaches are in use to determine the hydrological regime of rivers. Supervised approach, consisting in finding regularities in the multi-year hydrometric data series (Pardé 1957, Dynowska 1972, Lwowicz 1979) and non-supervised approach (Gottschalk 1985, Haines et al. 1988, Rotnicka 1988, Krasovskaia et al. 1994, Wrzesiński 2010a), in which classification procedures are used, most often - grouping (Krasovskaia and Gottschalk 2002, Wrzesiński 2010c). 
Studies of multiyear and seasonal specific discharge of rivers in Poland were conducted by Dynowska (1972), Fal and Bogdanowicz (2002) and Michalczyk (2009). Spatial variability of runoff in selected regions in Poland was presented, among others, by Jokiel and Bartnik (2001), Soja (2002), Jokiel (2004, 2010), Bartczak (2007a), Bogdanowicz (2009), Marszelewski and Dąbrowski (2010) and Wrzesiński (2010a, 2014). Main reason for variability of river runoff is sought in the climate variability, specifically in the context of the global warming (Arnell 1999). The influence of North Atlantic Oscillation (NAO) on runoff of rivers has been studied, for the area of Poland by Wrzesiński (2004, 2010b, 2011, 2013a, 2013b, 2014), for the area of Slovakia by Fendekova et al. (2014). Determination of the trend of runoff changes (ascending or descending) in the period of many years is strongly dependent on the period length. Studies of Pekarova et al. (2006) revealed that the analysis of the runoff of the main European rivers during last 150 years did not show any significant ascending or descending trend.

Numerous papers discuss the problem of uneven spread of runoff during a year caused by seasonality of the climate factors. Such studies were conducted by Bower et al. (2004) for British catchments, Renner and Bernhofer (2011) for the area of Saxony/Germany, Gottschalk et al. (2006) in the catchment of Moselle, Krasovskaia et al. (1999) for the Scandinavian rivers, Apsite et al. (2009) in Latvian rivers, Hanel et al. (2012) in Czech Republic. Apart from the climate factors, the influence on runoff from catchment has also various anthropogenic factors (Dynowska 1988, Gutry-Korycka 1993). The river runoff magnitude changes under the influence of, among others, urbanization (Czaja 1986, 2002, Jankowski 1986, 1988, Jokiel 2002) or hydrotechnical structures (Dynowska 1984, Kubiak 1997, 1999, Bartczak 2007b, Kubiak-Wójcicka 2004, 2010, Banach and Jańczak 2011, Kaniecki et al. 2012, Zhang et al. 2012) and others.

The Gwda and Drawa rivers are located in adjoining catchments with similar meteorological conditions, land use and energy potential. The rivers, however differ in the degree of development of hydrotechnical infrastructure. This last element was decisive in selecting both rivers for the comparison of hydrological conditions. According to Choiński (1986), both Gwda and Dra- wa catchments are the low hydrological activity areas. It means that their discharges in multiyear period are flat and hence more inert. Dynowska (1972) in turn, describes their regime as flat with spring flood and ground-rain-snow type of alimentation. The aim of the article is to compare hydrological regimes of the rivers Gwda and Drawa in the context of the differences in hydrotechnical development of both rivers.

\section{Methods}

The source materials include measurement and observation data collected by water gauge stations operated by the Institute of Meteorology and Water Management - National Research Institute. On the Gwda River, the water gauge station is located in Piła and on the Drawa River it is in Drawiny. Both gauge stations are located downstream of hydrotechnical structures, i.e. hydropower stations. The water gauge station in Piła has been operational since 1888. It is located at the $21.1 \mathrm{~km}$ of the Gwda River, $4.6 \mathrm{~km}$ downstream of the hydropower plant in Koszyce. Hydrological observations of the Drawa River in Drawiny had started before the observations in Piła, i.e. as early as in 1842 . The station is located at the $4.4 \mathrm{~km}$ of the Drawa River and the closest hydrotechnical structure, hydropower plant in Kamienna, is located $28.1 \mathrm{~km}$ from it.

The study of hydrological research was based on the analysis of changes of water stages, flow values and ice phenomena in the Gwda and Drawa rivers in the period of 1961-2010. The characteristic values (minimum, maximum and mean) of water stages and flow were analyzed as well as their amplitudes and fluctuation trends. Based on the difference between the maximum and the minimum values, the annual amplitudes of water stages were calculated. The quotient of the maximum and the minimum values allowed determining the annual irregularity coefficient. MS Excel spreadsheet exercising linear type of trend line was used to identify ascending or descending trends of particular indicators. Positive or negative trend equation sign determines ascending or descending trend of a given indicator, respectively. Statistical significance of the data was determined with the Student's t-test, at significance level 0.05 . 
In purpose to determine dry and wet years for both the rivers, two indicators were calculated: coefficient $\mathrm{k}$ and sum of $(\mathrm{k}-1)$. The coefficient $\mathrm{k}$ is a ratio of mean annual discharge to mean multiyear discharge. It depicts a relative deviation from the multiyear mean value and allows distinguish wet, average and dry years. A dry year has the coefficient $\mathrm{k}<1.0$, an average year $-\mathrm{k}=$ 1.0 and a wet year $-\mathrm{k}>1.0$. A dry and a wet year have been selected, based on the above definition. For those two years daily water stages course has been presented.

In purpose to determine sequences of wet or dry years, a cumulative curve of the coefficient $k$ (sum of (k-1)) has been utilized. If the mean annual discharge is less than the multiyear mean value during a few consecutive years, a descending discharge trend or a dry years sequence takes place. If the opposite condition applies - an ascending trend or a wet years sequence takes place.

In case of ice phenomena, the first and last dates and duration of particular ice forms i.e. frazil ice, fast ice, ice cover, floating ice and ice jam as well as the thickness of ice cover were analyzed.

The conclusions were based on the comparative analysis and the impacts were identified as the differences in processes described by the analyzed parameters. The work attempts to determine the impact of hydrotechnical structures, hydropower plants, on hydrological regimes of rivers.

\section{Study area}

\section{Physiographic conditions}

The catchments of the Gwda and Drawa rivers are located in the North European Plain (31), sub province of the South Baltic Lakeland (314-315), macroregion of the West Pomeranian Lakeland (314.4) and the South Pomeranian Lakeland (314.6-7) (Kondracki 2002). The Gwda and Drawa rivers are the $4^{\text {th }}$ order streams. Catchments of both rivers have similar physiogeographic characteristics. They feature fluvioglacial sands and gravels with multiple drainless depressions and a large number of lakes and forests. The Drawa River is the longest tributary of the Notec River $(185.9 \mathrm{~km})$. Compared to the Gwda River, it is characterized by higher lake density (3.9\%) and forest cover $(48.1 \%)$, greater denivelation (184.2 $\mathrm{m})$ and average longitudinal gradient (3\%o). The Gwda River, compared to the Drawa River, is a river with a larger catchment $\left(4944 \mathrm{~km}^{2}\right)$, river network density $\left(0.31 \mathrm{~km} \mathrm{~km}^{-2}\right)$ and average altitude (128.1 $\mathrm{m}$ a.s.l.) (Table 1).

Both rivers have similar hydrographic net. Their catchments are located in adjoining areas. Both rivers flow from the north to the south. Their largest tributaries are their right bank tributaries in the downstream sections. The largest tributary of the Gwda River is the Piława River, and of the Drawa River - the Mierzęcka Struga River. The largest lakes are located in the northern parts of their catchments and have similar surface areas. In the Gwda River catchment, the largest lake is Wielimie with the area of 1754.6 ha and, in the Drawa River catchment, it is Drawsko Lake with the surface area of 1781.5 ha (Jańczak 1996).

Catchments of both rivers are characterized by similar land use. Based on the Corine Land Cover (EEA 2006), it was established that the dominant land cover in the case of both areas are forests and semi-natural ecosystems. The Drawa River catchment has slightly more forests and semi-natural ecosystems (59.9\%) than the Gwda River $(51.1 \%)$. Both catchments are agricultural-forestry areas.

Table 1. Characteristics of the Gwda and Drawa rivers and their catchments (RZGW 2013)

\begin{tabular}{|l|c|c|}
\hline \multicolumn{1}{|c|}{ Characteristics } & Gwda River & Drawa River \\
\hline Stream order & 4th & 4th \\
\hline Tributary & right-bank of the Noteć R. & 185.9 \\
\hline Length $(\mathrm{km})$ & 145.1 & 3289 \\
\hline Catchment area $\left(\mathrm{km}^{2}\right)$ & 4944 & 0.26 \\
\hline River network density $\left(\mathrm{km} \mathrm{km}^{-2}\right)$ & 0.31 & 3.9 \\
\hline Lake density $(\%)$ & 2.5 & 48.1 \\
\hline Forest cover $(\%)$ & 23.0 & 184.2 \\
\hline Denivelation $(\mathrm{m})$ & 160.5 & 120.1 \\
\hline Average altitude $(\mathrm{m}$ a.s.l.) & 128.1 & 3 \\
\hline Average longitudinal gradient $(\% \mathrm{o})$ & 2 & \\
\hline
\end{tabular}




\section{Hydrotechnical works}

The Gwda River is heavily managed by hydrotechnical infrastructure. The hydrotechnical works mostly include small hydropower plants the majority of which were built before the World War II. In Western Pomerania, the first hydropower plant, previously known as hydropower plant Żarki, was constructed in Łomczewo in 1905. All other existing today hy- dropower plants on the Gwda River were built in 1905-1937 (Kubiak 1997). The newest hydropower plant started its operation in the town of Byszki (mouth section of the Gwda River) in 2012.

Presently, there are 12 hydropower plants located along the Gwda River (from its source to the mouth): Spore, Gołębiewo, Lubnica, Węgorzewo, Łomczewo (Żarki), Podgaje, Jastrowie, Ptusza, Tarnówka, Dobrzyca, Koszyce and Byszki (Fig.

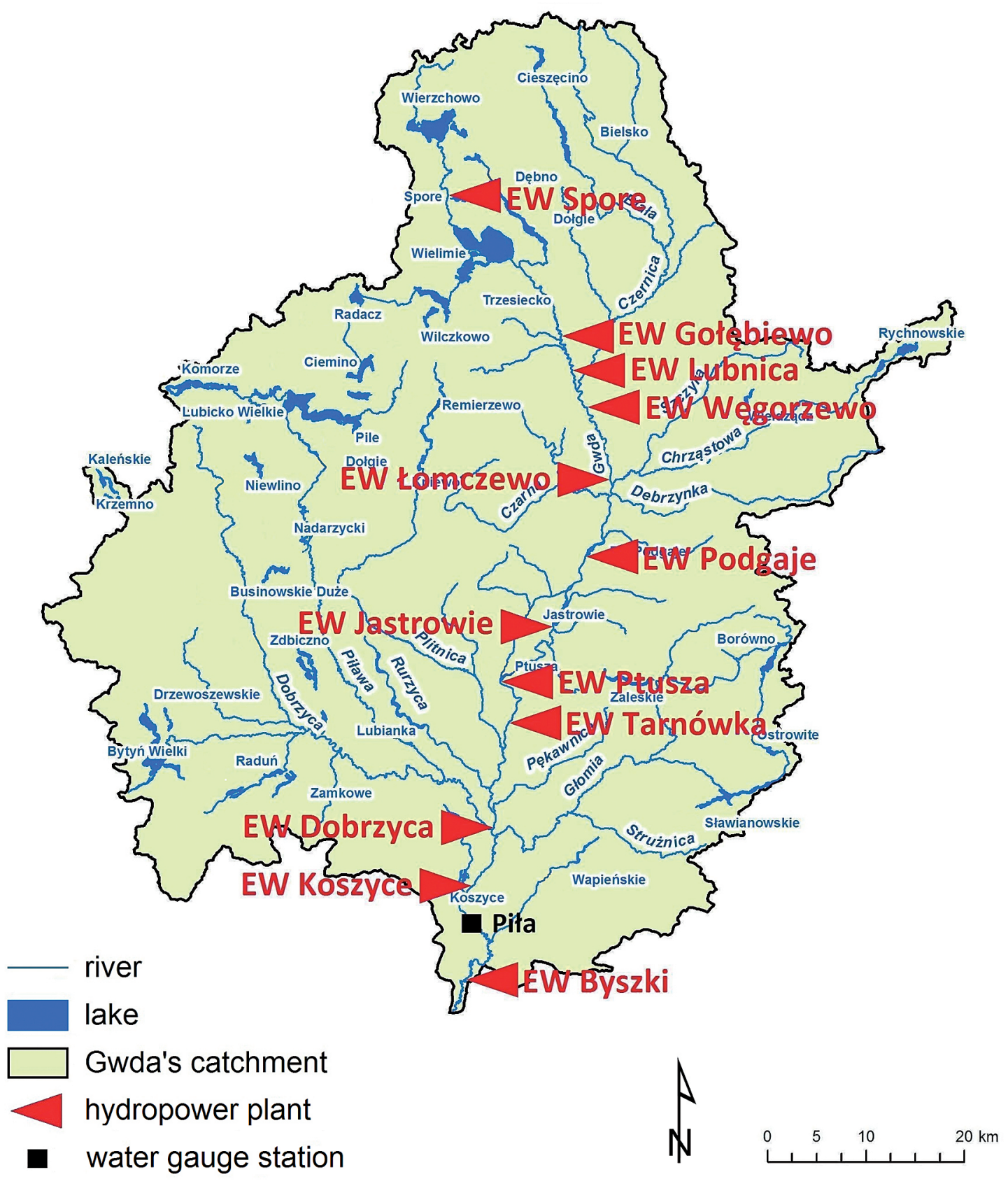

Fig. 1. Locations of hydropower plants on the Gwda River 
1). The capacity of hydropower plants located on the Gwda River varies from $15 \mathrm{~kW}$ (Hydropower Plant Spore) to $1900 \mathrm{~kW}$ (Hydropower Plant Podgaje). Hydropower plants with the largest capacity located on the Gwda River are: Podgaje $(1900 \mathrm{~kW})$, Dobrzyca $(1800 \mathrm{~kW})$, Jastrowie (1400 kW), Ptusza $(1100 \mathrm{~kW})$ and Koszyce $(1100 \mathrm{~kW})$. All of them are managed by the Hydropower Plants Ltd. in Samociążek. Accomplishing such a high capacity of hydropower plants was made possible by placing dams and building water reservoirs along the river. The total storage capacity of water reservoirs created for the needs of the hydropower plants is $c .17 \mathrm{M} \mathrm{m}^{3}$. In the case of these hydropower plants, the elevation drop from the top of the reservoir to the river below is the highest: Podgaje $(9.3 \mathrm{~m})$, followed by $(7.2$ $\mathrm{m})$, Ptusza (6.1 m), Dobrzyca (4.8 m) and Koszyce (3.5 m) (Enea 2013).

The Drawa River does not have such developed hydrotechnical infrastructure. There are only two hydropower plants: Kamienna, built before the World War I (1898) and Borowo (19161918) (Fig. 2). In the 1940's, there existed plans to build a cascade of hydroelectric plants on the Drawa River (Barnimie, Zatom, Moczele, Mostniki and the existing Kamienna) but they have never been realized. Hydropower plant Kamien-

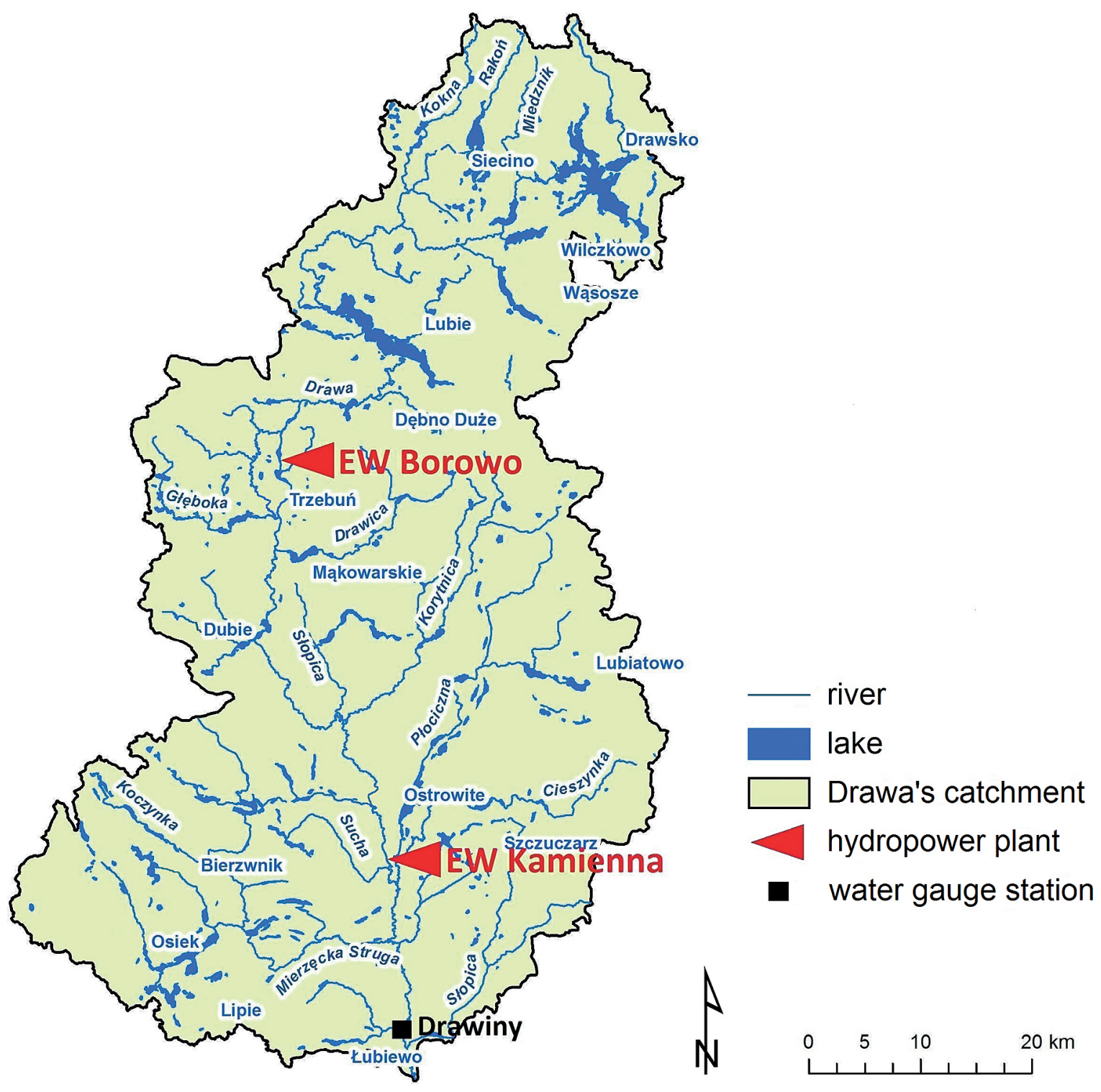

Fig. 2. Locations of hydropower plants on the Drawa River 
na with the capacity of $960 \mathrm{~kW}$ and the water elevation drop of $7.6 \mathrm{~m}$ is managed by Hydropower Plants Ltd. in Samociążek. It is one of the oldest operating hydropower plants in Poland. Hydropower Plant Borowo is located in the upper catchment and is managed by the Energia-Hydro Ltd. Its capacity is $450 \mathrm{~kW}$ and the water elevation drop - $8.6 \mathrm{~m}$ (Energa 2013). The Plant takes advantage of retention capacity of lakes Mielno and Zły Łęg.

\section{Results}

\section{Water stages}

The analysis of the impact of hydrotechnical works on the rivers first included changes of water stages of the Gwda and Drawa rivers in the period of 1961-2010. The mean annual water stages of the Gwda River show small decreasing trend (trend line $y=-0,038 x+141,8, R^{2}=0,001$ ) while, in the case of the Drawa River, it shows strong increasing trend (trend line $y=0,288 x+65,6, R^{2}$ $=0,186)$. The variability of characteristic values of water stage in the period of 1961-2010 is different for each river. The differences are reflected in the amplitude of annual water stages. The highest amplitude of water stages in the Gwda River was $204 \mathrm{~cm}$ in 1970 and the Drawa River it was $141 \mathrm{~cm}$ in 1963. The lowest amplitude, on the other hand, was $57 \mathrm{~cm}$ in 1993 in the Gwda River while in the Drawa River $36 \mathrm{~cm}$, twice, in 1973 and 1996.
Another analyzed element was the irregularity coefficient of water stages which is the ratio of the maximum and the minimum values in a given year. The Drawa River shows bigger irregularity of water stages than the Gwda River. The irregularity coefficient of water stages in the Drawa River ranges varied from 1.7 in 1996 to 5.1 in 1963. The irregularity coefficient of the Gwda River ranged from 1.6 in 2009 to 3.1 in 1982 (Fig. 3).

Both rivers differ in variability of daily water stage values. The analysis of daily water stages of both rivers in wet and dry years in the period of 1961-2010 showed that the Gwda River was characterized by considerable fluctuations of water in 24-hr periods. For the purpose of comparison, The courses of daily water stages of the Gwda and the Drawa in 1981 and in 2006 have been presented. 1981 is a year with high amplitude of water stages and the coefficient of water stage irregularity. It is also a year, in which the coefficient of discharge $(\mathrm{k})$ reached its highest values of the whole analyzed multiyear period. It meant that it was a wet year (Fig. 4). 2006, in turn, was a year with low amplitude of water stages, low coefficient of water stage irregularity and the lowest value of the coefficient $\mathrm{k}$ in the whole analysed multiyear period. It was named a dry year (Fig. 5). The sudden day to day changes of water stages in both, 1981 and 2006, in the Gwda River resulted from the operation of hydropower plants. Regulation of water stages by hydrotechnical works located along the Gwda River makes it possible to manage the quantity of inflowing water in such a way as to prevent the develop-

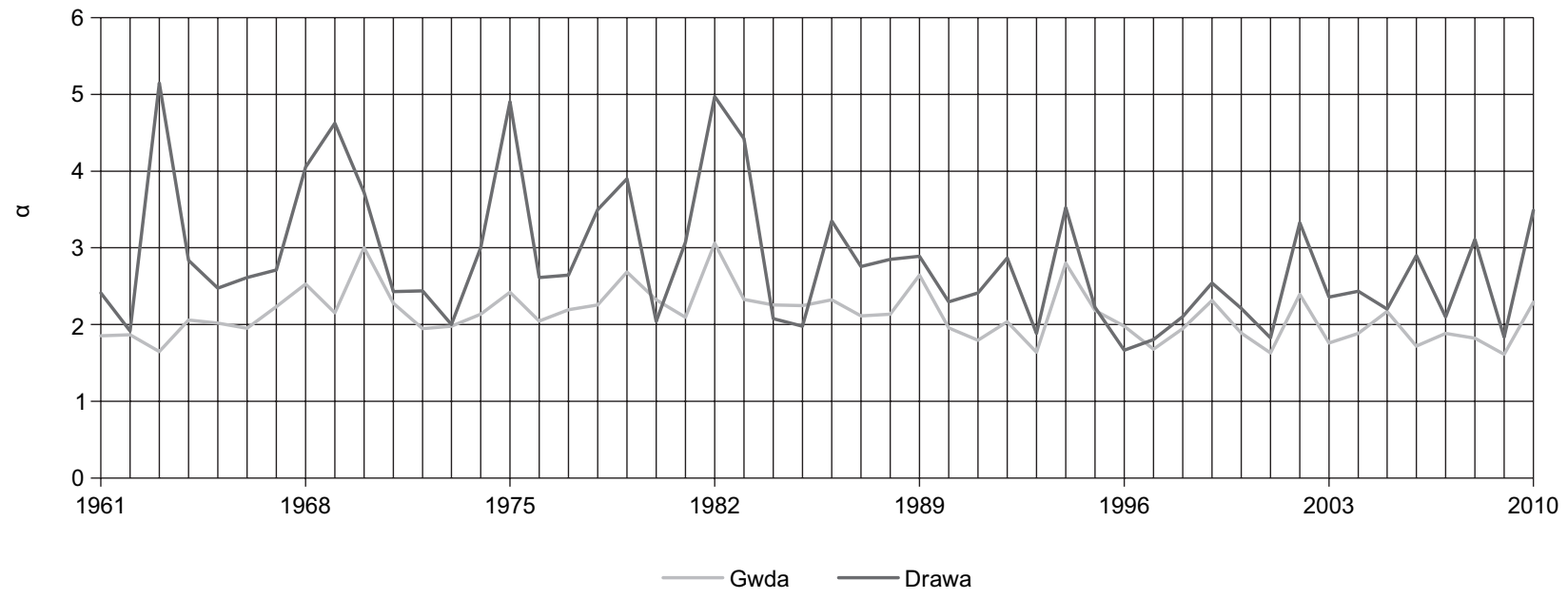

Fig. 3. Irregularity coefficient of water stages of the Gwda River in Piła and the Drawa River in Drawiny in hydrological years 1961-2010 


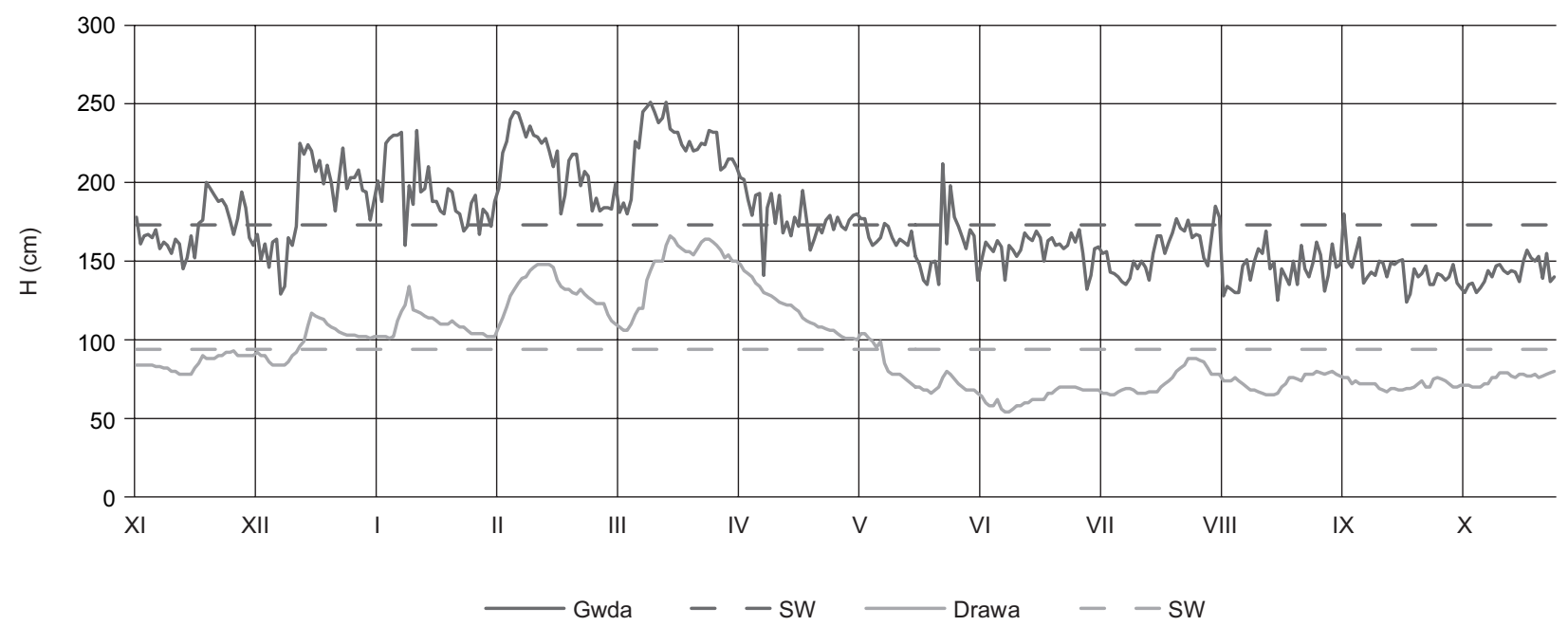

Fig. 4. Daily water stages of the Gwda River in Piła and the Drawa River in Drawiny in hydrological year 1981 (wet year)

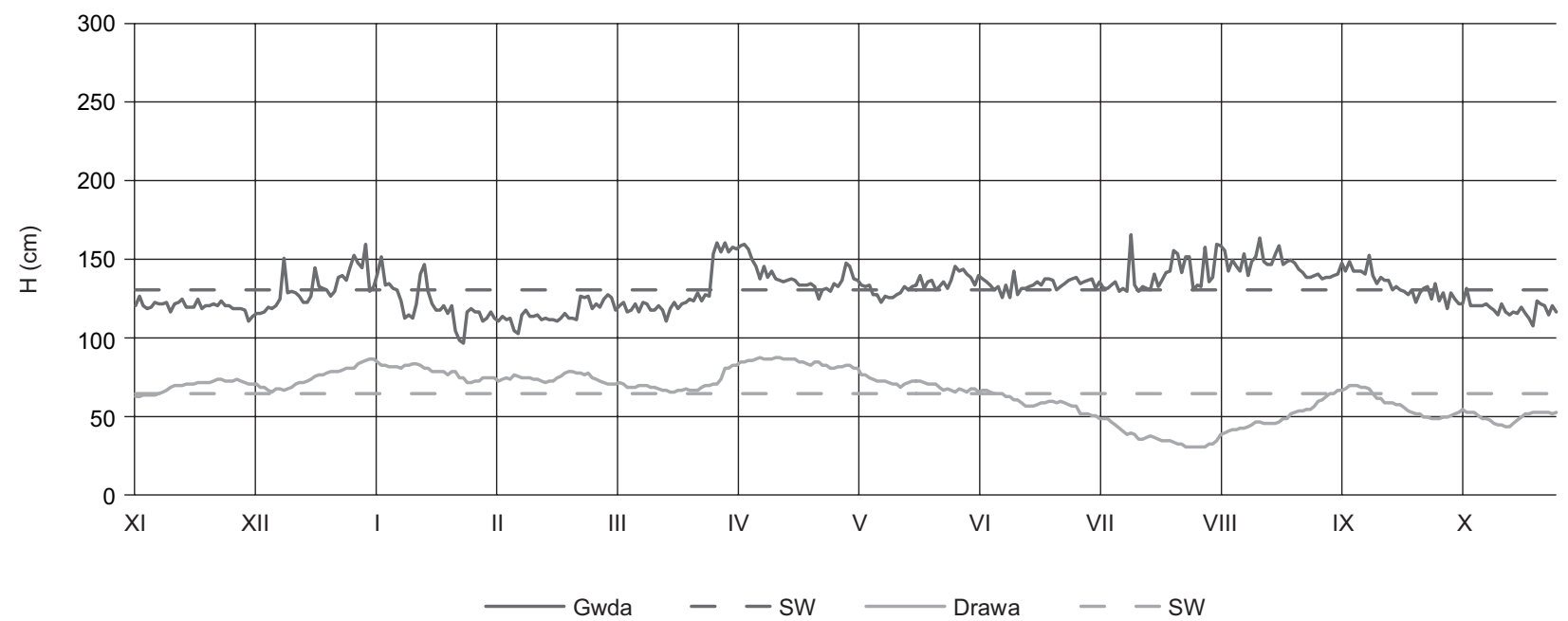

Fig. 5. Daily water stages of the Gwda River in Piła and the Drawa River in Drawiny in hydrological year 2006 (dry year)

ment of low flow. This possibility depends on the storage capacity of retention reservoirs located in the vicinity of hydropower stations. The course of the chart that presents water stages of the Drawa River, contrary to the Gwda River, is smooth, with no sudden change. In the wet year (1981), maximum daily water stage increase reached 15 $\mathrm{cm}$, while for the Gwda River it was $70 \mathrm{~cm}$. In the dry year (2006), maximum daily increase of water stage was significantly lower and reached $5 \mathrm{~cm}$ for the Drawa River and $32 \mathrm{~cm}$ for the Gwda River.

\section{Discharges}

The analysis of characteristic values of discharges in the Gwda and Drawa rivers indicated that both rivers had more similar patterns than patterns of water stage. The maximum value of mean annual discharge in the Gwda and Drawa rivers in the analyzed multi-year period

Table 2. Hydrological characteristics of the Gwda and Drawa River in 1961-2010

\begin{tabular}{|c|c|c|}
\hline Characteristics & Gwda River & Drawa River \\
\hline \multicolumn{3}{|c|}{ Characteristic values of water stages $(\mathrm{cm})$} \\
\hline NNW & 80 & 26 \\
\hline SSW & 141 & 73 \\
\hline WWW & 306 & 175 \\
\hline \multicolumn{3}{|c|}{ Characteristic values of water discharge $\left(\mathrm{m}^{3} \mathrm{~s}^{-1}\right)$} \\
\hline NNQ & 9.7 & 7.3 \\
\hline SSQ & 27.3 & 21.4 \\
\hline WWQ & 114.0 & 51.0 \\
\hline \multicolumn{3}{|c|}{ Characteristic values of specific runoff $\left(\mathrm{dm}^{3} \mathrm{~s}^{-1} \mathrm{~km}^{-2}\right.$} \\
\hline $\mathrm{NNq}$ & 2.1 & 2.2 \\
\hline SSq & 5.8 & 6.5 \\
\hline WWq & 24.2 & 15.5 \\
\hline
\end{tabular}




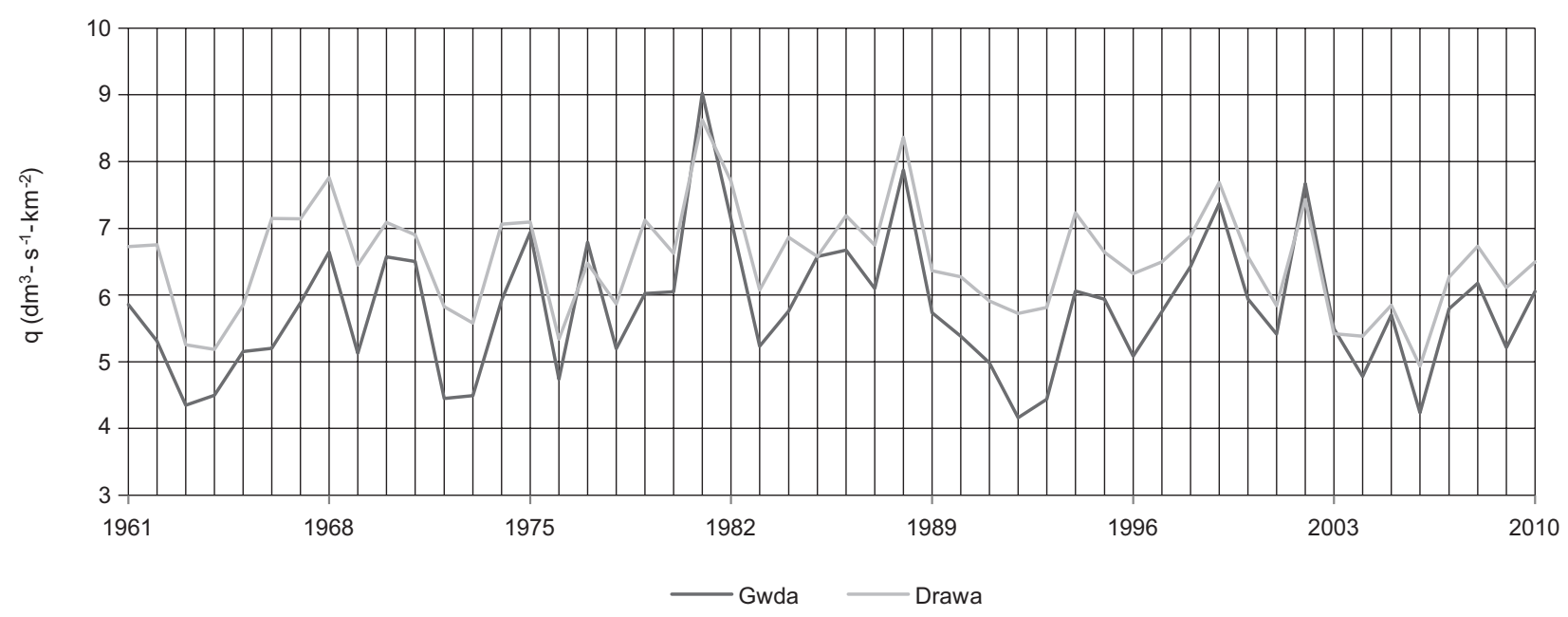

Fig. 6. Mean annual specific runoff of the Gwda River in Piła and the Drawa River in Drawiny in hydrological years 1961-2010

occurred in the same year - 1981. It the Gwda River in Piła it was $42.4 \mathrm{~m}^{3} \mathrm{~s}^{-1}$ and in the Drawa River in Drawiny $-28.3 \mathrm{~m}^{3} \mathrm{~s}^{-1}$. All the values of characteristic discharges are higher in the Gwda River than in the Drawa River. The largest difference $\left(63 \mathrm{~m}^{3} \mathrm{~s}^{-1}\right)$ was noted between the maximum values in a multiyear period in each river (Table 2).

The variation of annual specific runoff values of the Gwda and Drawa rivers showed even bigger similarities. The variations had repeatedly similar patterns. The extreme values of specific runoff in 1961-2010 are characterized by nearly similar values in the same years. The maximum specific runoff in both rivers was noted in 1981, and the minimal value occurred in 2006 (twice in the Gwda River - also in 1992). The values of specific runoff in the Gwda River varied from 4.2 to $9.0 \mathrm{dm}^{3} \mathrm{~s}^{-1} \mathrm{~km}^{-2}$, and 4.9 to $8.6 \mathrm{dm}^{3} \mathrm{~s}^{-1} \mathrm{~km}^{-2}$ in the Drawa River (Fig. 6). Significant differences were noted in case of the maximum specific runoff values. The values in the Gwda River were almost twice as big the values in the Drawa River (Table 2).

In order to determine increasing and decreasing discharge trends of the Gwda and Drawa rivers, the coefficient $k$ and the sum $(k-1)$ were calculated. Coefficient $\mathrm{k}$ is the ratio of mean annual flow value to a multiyear mean value. The value of $\mathrm{k}<1.0$ coefficient allows to qualify given year as dry, $k>1.0$ as wet and $k=1.0$ as average. The highest (1.6 and 1.3) and the lowest (0.7 and

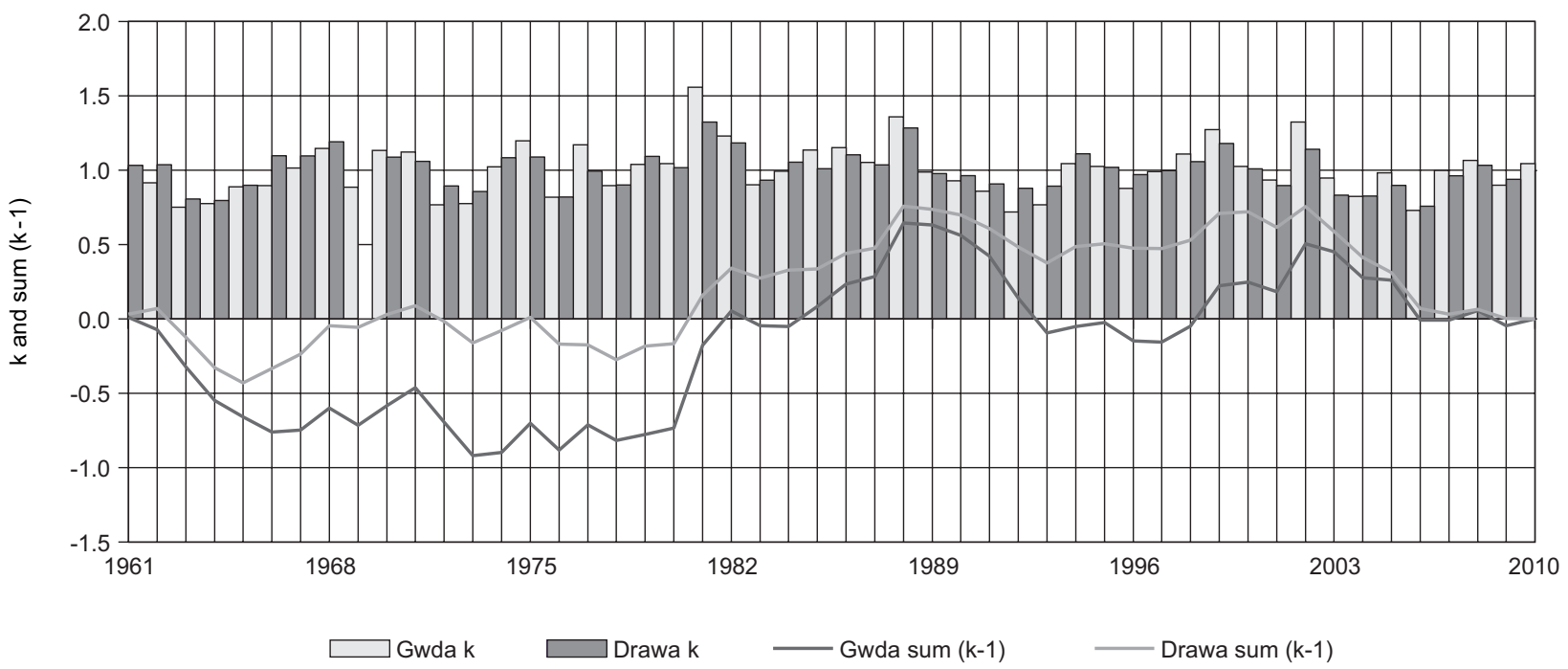

Fig. 7. Coefficient k and sum (k-1) for the Gwda River in Piła and the Drawa River in Drawiny in hydrological years 1961-2010 
$0.8)$ values of the coefficient $\mathrm{k}$ in the Gwda and Drawa rivers occurred in the same years of the analyzed period (1981 and 2006). The period with the strongest increasing trend (1.4 and 1.0) for the Gwda and Drawa rivers occurred in the same years from 1978 to 1990 . The strongest decreasing trend (-0.8) in the Gwda River took place in 1961-1966 and in the Drawa River in 2002-2007. This leads to conclusion that the Drawa River reacts sooner to changes in alimentation conditions than the Gwda River which first stores its water in retention reservoirs (Fig. 7).

\section{Ice phenomena}

Freezing of rivers impacts their water stages and flow values, ratio of runoff from river basins, conditions of the entire river ecosystem, operations of hydrotechnical works, causes damages of water structures and makes navigation impossible. Freezing of rivers very often creates flood hazard (Kornaś 2014). The variability of ice phenomena in the Gwda River in Piła and the Drawa River in Drawiny in the period of 1961-2010 showed significant differences. The maximum duration of ice phenomena occurrences in the Gwda River was 97 days in 1970 while in the Drawa River it was shorter almost by a half, i.e. 58 days in 1987. Of all the ice forms, the longest lasting was fast ice in both rivers (Gwda River - 97 days, Drawa River - 51 days) (Table 3). In the analyzed period, there were no occurrences of ice cover or ice jam in the Gwda River. The absence of ice cover at the Piła station resulted from the higher velocity downstream of hydropower plant and the pollutants discharged to the river from the city. Whereas in the Drawa River, all forms of ice phenomena were noted: frazil ice, fast ice, ice cover, floating ice and ice jam. The Drawa River, therefore, was characterized by higher variability of each ice phenomenon than the Gwda River in the studied multiyear period.

Ice cover occurred in the Drawa River three times: in 1963, 1970 and 1987. Its maximum duration was 32 days in 1963 . The maximum thickness of ice cover was $11 \mathrm{~cm}$ in 1987. The ice jam in the Drawa River in Drawiny was noted in only one day - January 31, 2010. Smaller variability was noted in the case of the first and last dates of occurrences of particular ice forms in a year. Ice phenomena in the Gwda River in Piła and in the Drawa River in Drawiny were first noted in the second half of November (Gwda River - November 17, Drawa River - November 16) and their latest thaw date was registered in the second half of March (Gwda River - March 22, Drawa River - March 18) (Table 3). The first and the last ice form to appear was fast ice in both rivers. The earliest date of ice cover in the Drawa River was December 24, 1970, and the latest date of ice cover occurrence was February 3, 1963.

\section{Conclusions}

The catchments of both the Gwda and the Drawa have similar physiogeographic characteristics, which include location, catchment size, geological structure, drainage density, land denivelations or land use. Significant factor of difference is a degree of hydrotechnical structure. There are 12 hydropower plants on the Gwda River, while on the Drawa River there are only 2. Furthermore, the plants on the Drawa River are located far from the water gauge.

The study included the analysis of mean annual, monthly and daily values of water stages, discharge and ice phenomena collected at the water gage Piła on the Gwda River and at the water gauge Drawiny on the Drawa River for the period of 1961-2010. The conclusions are as follows:

Table 3. Ice phenomena in the Gwda River in Piła and the Drawa River in Drawiny in 1961-2010

\begin{tabular}{|l|c|c|c|c|c|c|}
\hline \multirow{2}{*}{ Characteristics } & \multicolumn{3}{|c|}{ Gwda River } & \multicolumn{3}{c|}{ Drawa River } \\
\cline { 2 - 7 } & $\begin{array}{c}\text { Duration } \\
\text { (days) }\end{array}$ & First date & Last date & $\begin{array}{c}\text { Duration } \\
\text { (days) }\end{array}$ & First date & Last date \\
\hline Fast ice & 97 & 17.11 & 22.03 & 51 & 16.11 & 18.03 \\
\hline Frazil ice & 29 & 29.11 & 14.03 & 38 & 24.11 & 09.03 \\
\hline Floating ice & 14 & 28.12 & 09.03 & 7 & 13.12 & 17.02 \\
\hline Ice cover & 0 & - & - & 32 & 24.12 & 03.02 \\
\hline Ice jam & 0 & - & - & 1 & 31.01 & 31.01 \\
\hline Ice phenomena & 97 & 17.11 & 22.03 & 58 & 16.11 & 18.03 \\
\hline
\end{tabular}


- Mean annual water stages have slight negative trend on the Gwda River and a positive trend on the Drawa River,

- Annual water stage irregularity coefficient on the Gwda River is smaller than on the Drawa River,

- Day to day water stage changes are more sudden on the Gwda River than on the Drawa River,

- Mean annual runoff amplitude is higher on the Gwda River than on the Drawa River,

- Descending trend of mean annual runoff coefficient (k) is always longer on the Gwda River than on the Drawa River,

- Ascending trend of mean annual runoff coefficient is always shorter in the Gwda River than on the Drawa River,

- Duration of ice phenomena in a year is longer on the Gwda River and shorter on the Drawa River, but in the latter case, the range of the phenomena is larger.

\section{Acknowledgment}

We would like to thank two reviewers who provided feedback on the first version of this paper.

\section{References}

Apsite E., Bakute A., Rudlapa I., 2009. Changes of total annual runoff distribution, high and low discharges in Latvian rivers. In: Proceedings of the Latvian Academy of Sciences Section B 63(6): 279-286. DOI: 10.2478/v10046010-0004-y.

Arnell N.W., 1999. The effect of climate change on hydrological regimes in Europe: a continental perspectives. Global Environmental Change 9: 5-23.

Banach G., Jańczak J., 2011. Kształtowanie reżimu hydrologicznego Raduni przez zbiorniki wodne wykorzystywane w hydroenergetyce w latach 2006-2010 (Formation of the hydrologic regime of Radunia with water basins used for hydroenergy of 2006-2010). In: Marszelewski W. (ed.), Anthropogenic and Natural Transformations of Lakes, 5, Toruń: 17-24.

Bartczak A., 2007a. Wieloletnia zmienność odptywu w dorzeczu Zgłowiaczki (Long-term variability of the river outflow from Zgłowiączka basin). Prace IGiPZ PAN, Warszawa.

Bartczak A., 2007b. Wahania stanów wody (przepływów) rzeki Zgłowiączki wywołane pracą małej elektrowni wodnej (MEW) w Nowym Młynie (Fluctuations of water stages (flows) of the Zgłowiączki River resulting from the operation of hydropower plant in Nowy Młyn). Nauka Przyroda Technologie 1: 2-13.

Bogdanowicz R., 2009. Zasoby rzek Przymorza i ich zmienność (Water resources of coastal rivers and their variabili- ty). In: Bogdanowicz R., Fac-Beneda J. (eds), Zasoby i ochrona wód. Obieg wody i materii w zlewniach rzecznych. Fundacja Rozwoju Uniwersytetu Gdańskiego, Gdańsk: 47-62.

Bower D., Hannah D.M., McGregor G.R., 2004. Techniques for assessing the climatic sensitivity of river flow regime. Hydrological Processes 18: 2515-2543.

Choiński A., 1986. Uwarunkowania i zmienność aktywności hydrologicznej rzek polskich (The conditions and variability of hydrologic activity of the rivers in Poland). In: Kaniecki A. (ed.), Hydrologia regionalna i procesy hydrologiczne w zlewniach. Poznań: 47-52.

Czaja S., 1986. Wpływ gospodarczej działalności człowieka na reżim odpływu Brynicy (The influence of economic human activity on the runoff regime of the Brynica River). In: Kaniecki A. (ed.), Hydrologia regionalna i procesy hydrologiczne w zlewniach, Materiały konferencyjne, 15-17 września 1986, Poznań: 53-58.

Czaja S., 2002. Zmiany struktury i reżimu odpływu rzecznego na obszarach górniczo-przemysłowo-miejskich (Changes in river runoff structure and regime in mine-industrial-urban areas). In: Ciupa T., Kupczyk E., Suligowski R. (eds), Obieg wody w zmieniajacym się środowisku. Prace Instytutu Akademii Świętokrzyskiej, 7, Kielce: 65-76.

Dynowska I., 1972. Typy reżimów rzecznych w Polsce (Types of river regimes in Poland). Zeszyty Naukowe Uniwersytetu Jagiellońskiego, Prace Geograficzne 28.

Dynowska I., 1984. Zmiana reżimu odpływu w wyniku oddziaływania zbiorników retencyjnych (Runoff regime change as a result of influence of storage reservoirs). Czasopismo Geograficzne 55(3): 301-316.

Dynowska I. (ed.), 1988. Antropogeniczne uwarunkowania zmian odpływu i reżimu rzek w różnych regionach Polski (Anthropogenic determinants of changes in river runoff and regimen in different regions of Poland). Dokumentacja Geograficzna 4.

EEA [European Environment Agency], 2006. Corine Land Cover. Online www.eea.europa.eu (accessed 1 May 2013).

Enea, 2013. Enea. Online: www.ew.koronowo.pl (accessed 10 June 2013).

Energa, 2013. Energa. Online: www.energa-hydro.pl (accessed 10 June 2013).

Fal B., Bogdanowicz E., 2002. Zasoby wód powierzchniowych Polski (Resources of surface water in Poland). Wiadomości IMGW 26(2): 3-38.

Fendekova M., Pekarova P., Fendek M., Pekar J., Škoda P., 2014. Global drivers effect in multi-annual variability of runoff. Journal of Hydrology and Hydromechanics, 62(3): 169-176. DOI: 10.2478/johh-2014-0027.

Gottschalk L., 1985. Hydrological regionalisation of Sweden. Hydrological Sciences Journal 30: 65-83.

Gottschalk L., Krasovskaia I., Leblois E., Sauquet E., 2006. Mapping mean and variance of runoff in a river basin. Hydrology and Earth System Sciences 1: 469-484.

Gutry-Korycka M., 1993. Wpływ urbanizowania i uprzemysławiania (Influence of urbanization and industrialization). In: Dynowska I. (ed.), Przemiany stosunków wodnych w Polsce w wyniku procesów naturalnych $i$ antropogenicznych. UJ, Kraków: 344-354.

Gutry-Korycka M. (ed.), 2001. Geograficzne uwarunkowania ustroju rzek (Geographic determinants of river regime). WSGiSR UW, Warszawa.

Haines A.T., Finlyson B.L., McMahon T.A., 1988, A global classification of river regimes. Applied Geography 8: 255272. 
Hanel M., Vizina A., Máca P., Pavlásek J., 2012. A multi-model assessment of climate change impact on hydrological regime in the Czech Republic. Journal of Hydrology and Hydromechanics 60(3): 152-161.

Jankowski A.T., 1986. Ocena wpływu gospodarczej działalności człowieka na zmiany odpływu Szotkówki i Leśnicy w latach 1963-1980 (Assessment of human economic activity influence on runoff changes of the Szotkówka River and the Leśnica River in the period of 1963-1980). In: Kaniecki A. (ed.) Hydrologia regionalna i procesy hydrologiczne w zlewniach. Poznań: 235-241.

Jankowski A.T., 1988. Wpływ przemysłu i urbanizacji na zmiany odpływu Rawy (próba oceny) (Influence of industry and urbanization on runoff changes of the Rawa River - an assessment attempt). In: Dynowska I. (ed.), Antropogeniczne uwarunkowania zmian odptywu $i$ reżimu rzek w różnych regionach Polski. Dokumentacja Geograficzna 4: 51-63.

Jańczak J. (ed.), 1996. Atlas jezior Polski (Atlas of Polish lakes). Tom II, IMGW, Bogucki Wydawnictwo Naukowe, Poznań.

Jokiel P., 2002. Zagospodarowanie terenu i jego rola w obiegu wody na przykładzie małej zlewni w strefie podmiejskiej Łodzi (Land use and its role in a hydrological cycle giving small drainage basin in the suburb of Łódź as an example). In: Ciupa T., Kupczyk E., Suligowski R. (eds), Obieg wody w zmieniajacym się środowisku. Prace Instytutu Geografii Akademii Świętokrzyskiej, 7, Kielce: 95-112.

Jokiel P., 2004. Zasoby wodne środkowej Polski na progu XXI wieku (Water resources of the central Poland at the beginning of the twentieth century). Wydawnictwo UŁ, Łódź.

Jokiel P., 2010. Niżówki i odpływy niżówkowe w małych rzekach środkowej Polski w drugiej połowie XX wieku (Low-water and low-water's runoffs in small rivers of the central Poland in second half of the twentieth century). In: Wrzesiński D. (ed.), Odptyw rzeczny i jego lokalne uwarunkowania. Bogucki Wydawnictwo Naukowe, Poznań: 87-98.

Jokiel P., Bartnik A., 2001. Zmiany w sezonowym rozkładzie odpływu w Polsce środkowej w wieloleciu 1951-1998 (Changes in seasonal distribution of runoff in central Poland in the period of 1951-1998). Wiadomości IMGW 2: 3-17.

Kaniecki A., Woźniak A., Kornaś M., 2012. Wykorzystanie wód dla potrzeb młynarskich na obszarze międzyrzecza Warty i Prosny w XVI wieku (The use of water for needs of milling industry in the interfluvial area between the Warta and Prosna Rivers in the $16^{\text {th }}$ Century). Przeglad Geofizyczny 57(3-4): 379-391.

Kondracki J., 2002. Geografia regionalna Polski (Regional geography of Poland). Wydawnictwo Naukowe PWN, Warszawa.

Kornaś M., 2014. Ice phenomena in the Warta River in Poznań in 1961-2010. Quaestiones Geographicae 33(1): 51-59.

Krasovskaia I., Arnell N.W., Gottschalk L., 1994. Flow regimes in northern and western Europe: development and application of procedures for classifying flow regimes. IAHS Publications 221: 185-192.

Krasovskaia I., Gottschalk L., 2002. River flow regimes in changing climate. Hydrological Sciences Journal 4: 597-609.

Krasovskaia I., Gottschalk L., Kundzewicz Z.W., 1999. Dimensionality of Scandinavian river flow regimes. $\mathrm{Hy}$ drological Sciences-Journal-des Sciences Hydrologiques 44(5): 705-723.
Kubiak K., 1997. Energetyczne wykorzystanie rzeki Gwdy (The use of water for energy production). Kaskada, 1, Kwartalnik wydawany pod egidą Fundacji „Kaskada Dolnej Wisły", Włocławek: 22-26.

Kubiak K., 1999. Wptyw elektrowni wodnych na Gwdzie na reżim hydrologiczny rzeki (Impacts of hydropower plants on the Gwda River on its hydrological regime). Acta Universitatis Nicolai Copernici, Geografia, 103: 143-153.

Kubiak-Wójcicka K., 2004. Kształtowanie się odpływu rzeki Gwdy w wybranych profilach wodowskazowych pod wpływem zabudowy hydrotechnicznej (Formation of the Gwda River's runoff in selected water gauge stations under the influence of hydrotechnic structures). In: Kejna M., Uscka J. (eds), Zintegrowany monitoring środowiska przyrodniczego. Biblioteka Monitoringu Środowiska, Oficyna Wydawnicza Turpress, Torun: 219-226.

Kubiak-Wójcicka K., 2010. Zmienność przepływów i zasobów wodnych rzeki Gwdy (The variability of discharge and water resources of the Gwda River). In: Wrzesiński D. (ed.), Odptyw rzeczny i jego lokalne uwarunkowania. Bogucki Wydawnictwo Naukowe, Poznań: 99-107.

Lwowicz M.I., 1979, Zasoby wodne świata (Water resources of the World). Wydawnictwo Naukowe PWN, Warszawa.

Marszelewski W., Dąbrowski M., 2010. Wieloletnie tendencje zmian odpływu Biebrzy (Long term trend of runoff changes of the Biebrza River). In: Wrzesiński D. (ed.), Odptyw rzeczny i jego lokalne uwarunkowania. Bogucki Wydawnictwo Naukowe, Poznań: 109-120.

Michalczyk Z., 2009. Średnie i skrajne odpływy z obszaru Polski (Average and extreme runoff from the Polish territory). In: Bogdanowicz R., Fac-Beneda J. (ed.), Zasoby $i$ ochrona wód. Obieg wody $i$ materii w zlewniach rzecznych. Fundacja Rozwoju Uniwersytetu Gdańskiego, Gdańsk: 37-46.

Pardé M., 1957. Rzeki (River). Wydawnictwo Naukowe PWN, Warszawa.

Pekarova P., Miklanek P., Pekar J., 2006. Long-term trends and runoff fluctuations of European rivers. In: Climate Variability and Change - Hydrological Impacts (Proceedings of the Fifth FRIEND World Conference held at Havana, Cuba, November 2006), IAHS Publication 308: 520-525.

Piętka I., 2009. Wieloletnia zmienność wiosennego odptywu rzek polskich (Long-term variations of spring runoff of Polish rivers). Prace i Studia Geograficzne 43: 81-95.

Renner M., Bernhofer C., 2011. Long term variability of the annual hydrological regime and sensitivity to temperature phase shifts in Saxony/Germany. Hydrology and Earth System Sciences 15: 1819-1833.

Rotnicka J., 1988. Taksonomiczne podstawy klasyfikacji reżimu rzecznego na przykładzie zlewni Odry i rzek Przymorza (Taxonomic foundations of the classification of the river regime on the example of the Odra drainge basin and Przymorze rivers). Seria Geografia, 40, Wydawnictwo UAM, Poznań.

RZGW [Regionalny Zarząd Gospdarki Wodnej], 2013. Region wodny. Online: www.poznan.rzgw.gov.pl/region-wodny (accessed 14 June 2013).

Soja R., 2002. Hydrologiczne aspekty antropopresji w polskich Karpatach (Hydrological aspects of human impact in the Polish Carpathians). Prace Geograficzne PGPZ PAN, 186.

Wrzesiński D., 2004. Flow regimes of river of northern and central Europe in various circulation periods of the North Atlantic Oscillation (NAO). XXIII Nordic Hydrological Conference, Tallinn, NHP Report, 48: 670-679. 
Wrzesiński D., 2010a. Detekcja zmian reżimu hydrologicznego Warty w profilu Poznania w latach 1822-2005 (Detection of changes in hydrologic regime of Warta at water gauge station Poznan in the period of 1822-2005). In: Wrzesiński D. (ed.), Odpływ rzeczny i jego lokalne uwarunkowania. Bogucki Wydawnictwo Naukowe, Poznań: 135151.

Wrzesiński D., 2010b. Odpływ rzek w Polsce w różnych fazach Oscylacji Północnoatlantyckiej (River runoff in Poland in various stages of North Atlantic Oscillation). Badania Fizjograficzne, Seria A61: 129-144.

Wrzesiński D., 2010c. Przestrzenne zróżnicowanie stabilności reżimu odpływu rzek europejskich (Spatial differentations of regime stability European rivers regime runoff). Studia i Prace z Geografii i Geologii 3, Poznań.

Wrzesiński D., 2011. Regional differences in the influence of the North Atlantic Oscillation on seasonal river runoff in Poland. Quaestiones Geographicae 30(3): 127-136.
Wrzesiński D., 2013a. Entorpia odpływu rzek w Polsce (Entorpy of river flows in Poland). Studia $i$ Prace Geografii $i$ Geologii 33, Poznań.

Wrzesiński D., 2013b. Uncertainty of flow regime characteristics of river in Europe. Quaestiones Geographicae 32(1): 43-53.

Wrzesiński D., 2014. Detekcja zmian reżimu odpływu rzek w Polsce (Detection of changes in runoff regime of rivers in Poland). In: Ciupa T., Suligowski R. (eds), Woda w mieście. Monografie Komisji Hydrologicznej PTG, 2: 319-330.

Zhang Y., Arthington A.H., Bunn S.E., Mackay S., Xia J., Kennard M., 2012. Classification of flow regimes for environmentl flow assessment in regulated rivers: The Huai River basin, China. River Research Applications 28: 989-1005. DOI: 10.1002/rra.1483. 